\title{
Curcumin: A natural antiinflammatory agent
}

\author{
K. Kohli, J. Ali, M. J. Ansari, Z. Raheman
}

Department of

Pharmaceutics, Faculty of

Pharmacy, Jamia Hamdard

University, Hamdard Nagar, New Delhi, India

Received: 24.3.2004

Revised: 13.9.2004

Accepted: 20.9.2004

Correspondence to:

K. Kohli

E-mail:

kanchankohli@hotmail.com

\begin{abstract}
Extensive scientific research on curcumin, a natural compound present in the rhizomes of plant Curcuma longa Linn., demonstrated its antiinflammatory action. Curcumin was found to inhibit arachidonic acid metabolism, cyclooxygenase, lipoxygenase, cytokines (Interleukins and tumour necrosis factor) Nuclear factor- $\mathrm{B}$ and release of steroidal hormones. Curcumin was reported to stabilize lysosomal membrane and cause uncoupling of oxidative phosphorylation besides having strong oxygen radical scavenging activity, which was responsible for its antiinflammatory property. In various animal studies, a dose range of 100$200 \mathrm{mg} / \mathrm{kg}$ body weight exhibited good antiinflammatory activity and seemed to have negligible adverse effect on human systems. Oral $L_{50}$ in mice was found to be more than $2.0 \mathrm{~g} / \mathrm{kg}$ body weight.
\end{abstract}

KEY WORDS: Cyclo-oxygenase (COX); free radical scavenger; inflammation.
The rhizome of turmeric is widely used in indigenous medicine. ${ }^{[1]}$ A paste made from powdered rhizome of Curcuma longa Linn., mixed with slaked lime applied locally, is an ancient household remedy for sprains, muscular pain and inflamed joints. It is also applied in poultices to relieve pain and inflammation. ${ }^{[2]}$ The volatile oil and curcumin obtained from C. longa exhibit potent antiinflammatory effect. ${ }^{[3]}$

Curcumin is yellow coloured phenolic pigment, ${ }^{[4]}$ obtained from powdered rhizome of $C$. longa Linn. (FamilyZingiberaceae). It is the major constituent of the oleoresin of turmeric. In the crude extract of rhizomes of $C$. longa about $70-76 \%$ curcumin is present along with about $16 \%$ demethoxycurcumin and $\mathbf{8 \%}$ bisdemethoxycurcumin. It is extensively used for imparting colour and flavour to the food and in the traditional Indian medicine, turmeric powder is used to treat a wide variety of diseases. Extensive scientific research on curcumin have demonstrated a wide spectrum of therapeutic effects such as antiinflammatory, ${ }^{[5]}$ antibacterial, ${ }^{[6]}$ antiviral, ${ }^{[7]}$ antifungal, ${ }^{[8]}$ antitumor, ${ }^{[9]}$ antispasmodic ${ }^{[10]}$ and hepatoprotective. ${ }^{[11]}$ Recently, its potential utility in autoimmune deficiency syndrome (AIDS) has been demonstrated. ${ }^{[12]-[14]}$ In this review, the findings on curcumin's antiinflammatory activity and its mechanisms are presented.

\section{Preclinical studies}

\section{Curcumin and antiinflammatory activity}

Arora et al reported antiinflammatory activity in different fractions of the petroleum ether extract of $C$. longa. ${ }^{[5]}$ The total petroleum ether extract of the rhizome of turmeric and two of its fractions A and B were evaluated for their antiinflammatory activity in albino rats (180-200 g) and compared with that of hydrocortisone acetate and phenylbutazone. It was found that the antiinflammatory activity of the total petroleum ether extract was less than the individual fractions $\mathrm{A}$ and $\mathrm{B}$. The fractions were almost as active as hydrocortisone acetate in the inflammation induced by cotton pellet method. Curcumin isolated from the alcoholic extract of turmeric has been shown to be a useful antiinflammatory agent. In subacute toxicity experiments, no significant toxic side effects were observed in rats when the extract was administered for 4 weeks at the dose level of $1-2 \mathrm{~g} / \mathrm{kg}$. Oral $\mathrm{LD}_{50}$ was found to be $12.2 \mathrm{~g} / \mathrm{kg}^{[5]}$ Recently, antiinflammatory activity of curcumin has been demonstrated in acute and chronic models of inflammation in rats and mice. ${ }^{[15],[16]}$ In rats with Freud's adjuvant-induced arthritis, administration of curcumin significantly reduced the inflammatory swelling compared to control. ${ }^{[16]}$ Oral doses up to $160 \mathrm{mg} / \mathrm{kg}$ of curcumin failed to prevent phenylquinoneinduced inflammation in mice. In instances of acute inflammation, oral administration of curcumin was found to be as effective as cortisone or phenylbutazone, whereas in chronic inflammation it was only half as effective. ${ }^{[17]}$ Curcumin may also be applied topically to animal skin to counteract inflammation and irritation associated with inflammatory skin conditions and allergies. ${ }^{[17]}$

Natural analogues of curcumin

Two naturally occurring analogues of curcumin, Feruloyl 
4-hydroxy cinnamoyl methane (FHM) and bis-(4-hydroxy cinnamoyl) methane (BHM) were isolated from the alcoholic extract of turmeric. ${ }^{[18]}$ Both were screened for antiinflammatory activity using carrageenin-induced rat paw edema and compared with sodium curcuminate and phenylbutazone. ${ }^{[19]}$ The FHM was found to be more potent and the activity with 30 $\mathrm{mg} / \mathrm{kg}$ dose of FHM was found to be equivalent to that of 100 $\mathrm{mg} / \mathrm{kg}$ of phenylbutazone. ${ }^{[19]}$ Curcumin analogues revealed a dose-dependent effect up to the dose of $30 \mathrm{mg} / \mathrm{kg}$. Further increase in dose resulted in decreased antiinflammatory activity. ${ }^{[19]}$

\section{Semi-synthetic curcumin}

As curcumin is insoluble in water, its water-soluble semisynthetic derivatives were studied for antiinflammatory activity. Ghatak et al prepared sodium phenate of curcumin and demonstrated its antiinflammatory activity. ${ }^{[20]}$ They found that sodium phenate of curcumin showed better antiinflammatory activity than curcumin and hydrocortisone acetate in experimental inflammation induced by carrageenin and formalin in albino rats. Mukhopadhayay et al have studied the structure-activity relationship (SAR) with respect to antiinflammatory activity in a series of curcumin analogues. ${ }^{[21]}$ They reported that sodium salt of curcumin was found to be most effective in carrageenin-induced rat hind paw oedema among curcumin and some of its semi-synthetic analogues.

\section{Clinical trials}

Deodhar et al have studied the antiinflammatory action of curcumin in patients with rheumatoid arthritis. The study demonstrated a significant improvement in the duration of morning stiffness, walking time and joint swelling, with curcumin, which was almost comparable to phenylbutazone. ${ }^{[22]}$ Satoskar et al evaluated the antiinflammatory property of curcumin in patients with postoperative inflammation. The effect of the drug on individual parameters revealed that phenylbutazone and curcumin had better antiinflammatory responses in these patients compared to the placebo. Curcumin was found better than phenylbutazone in reducing spermatic cord oedema and tenderness. ${ }^{[23]}$

Kuttan et al reported that an ethanolic extract of turmeric or a curcumin ointment provided symptomatic relief in patients with cancers of oral cavity, breast, vulva and skin. Out of 62 patients, only one showed adverse reaction. ${ }^{[24]}$

Lal et al studied the efficacy of curcumin in the management of chronic anterior uveitis (CAU). ${ }^{[25]}$ Curcumin was administered orally to patients suffering from CAU at a dose of $375 \mathrm{mg}$ three times per day for 12 weeks. Of the 53 patients enrolled, only 32 completed the 12 week study. They were divided into two groups: 18 patients received curcumin alone while 14 patients, who had a strong purified protein derivative (PPD) reaction, received antitubercular treatment in addition to curcumin. The patients from both the groups showed improvement after 2 weeks of treatment. All the patients who received curcumin alone improved well while those who received curcumin and antitubercular therapy showed a response rate of $86 \%$. Follow-up of all the patients for the next 3 years indicated a recurrence rate of $55 \%$ in the first group and of $36 \%$ in the second group. About 4 of 18 patients (22\%) in the first group and 3 of the 14 patients (21\%) in the second group lost their vision in the follow-up period due to various complications such as vitritis, macular oedema, central venous block, cataract formation, glaucomatous optic nerve damage, etc. None of the patients reported any side effect during the treatment. Corticosteroid therapy is presently the only available standard treatment for this disease. Lack of side effects with curcumin is its greatest advantage compared with corticosteroids.

Lal $e t$ al described for the first time the clinical efficacy of curcumin in the treatment of patients suffering from idiopathic inflammatory orbital pseudotumours. ${ }^{[26]}$ Curcumin was administered orally at a dose of $375 \mathrm{mg}$ thrice a day orally for a period of 6-22 months in eight patients. They were followed up for a period of 2 years at three monthly intervals. Five patients completed the study; out of which four recovered completely and in one patient, the swelling regressed completely with some persistent limitation of movement. No side effect was noted in any of the patients and there was no recurrence. Though it was suggested that curcumin could be used as a safe and effective drug in the treatment of idiopathic inflammatory orbital pseudotumours, a large multicentric trial with adequate number of patients is required to confirm the beneficial effects of curcumin.

\section{Mechanism of action of curcumin}

Nonsteroidal antiinflammatory agents may act via single or combination of any of the mechanism involving inhibition of arachidonic acid metabolism, inhibition of cyclo-oxygenase (COX)/inhibition of the PG synthesis, inhibition of lipoxygenase (LOX), inhibition of cytokines (IL, TNF, etc.), release of steroidal hormones from the adrenals, stabilization of lysosomal membrane and uncoupling of oxidative phosphorylation, etc.

Srivastava et al demonstrated that curcumin inhibited the incorporation of $\left[{ }^{14} \mathrm{C}\right]$ arachidonic acid (AA) into platelet phospholipids and inhibited the deacylation of AA-labelled phospholipids (liberation of free AA) on stimulation with calcium ionophore A23187..$^{[27],[28]}$ Rat peritoneal macrophages preincubated with $10 \mu \mathrm{M}$ curcumin or capsaicin for $1 \mathrm{~h}$ inhibited the incorporation of AA into membrane lipids by 82 and $76 \%$, respectively; prostaglandin $\mathrm{E}_{2}$ by $45 \%$ and $48 \%$; leukotriene $\mathrm{B}_{4}$ by $61 \%$ and $46 \%$ and leukotriene $C 4$ by $34 \%$ and $48 \%$, respectively. ${ }^{[29]}$ Curcumin appears to block the synthesis of certain prostaglandins through inhibition of COX enzyme. ${ }^{[30],[31]}$ Ramsewak et al. demonstrated that curcumins I-III were active against COX-I enzyme with $125 \mu \mathrm{g} / \mathrm{ml}$ and showed 32\%, 38.5\% and $39.2 \%$ inhibition of the enzyme, respectively. Curcumins I-III also showed $89.7 \%, 82.5 \%$ and $58.9 \%$ inhibition, respectively, of the COX-II enzyme with $125 \mu \mathrm{g} / \mathrm{ml}^{\text {[32] }}$

Curcumin reduces pro-inflammatory leukotriene synthesis via inhibition of LOX enzyme. ${ }^{[33-[35]}$ Flynn et al studied the inhibitory activities of curcuminoids and yakuchinones on the 5-hydroxy-eicosatetranoic acid (5-HETE). Various diarylheptonoids, including curcumin, were found to be potent inhibitors of 5-HETE productions by intact human neutrophils with $\mathrm{IC}_{50}$ values ranging from 4 to $8 \mu \mathrm{M} .^{[36]}$ Curcumin reduces the neutrophil infiltration in inflammatory conditions ${ }^{[37 \mid-[39]}$ and inhibit platelet aggregation. ${ }^{[40],[41]}$ It is also a potent inhibitor of 
pro-inflammatory cytokines (IL and TNF). ${ }^{[42-[46]}$ The oxygen radical scavenging activity ${ }^{[47],[48]}$ of curcumin has also been implicated in its antiinflammatory effects. ${ }^{[49]}$

\section{Molecular mechanism and biochemical changes}

\section{Inhibition of $\mathrm{COX}$}

Zhang et al investigated whether curcumin inhibited chenodeoxycholate (CD)-or phorbol ester (phorbol 12-myristate 13-acetate, PMA)-mediated induction of COX-2 in several gastrointestinal cell lines (SK-GT-4, SCC450, IEC-18 and HCA7). ${ }^{[50]}$ Treatment with curcumin suppressed CD- and PMAmediated induction of COX-2 protein and synthesis of prostaglandin $\mathrm{E}_{2}$. Curcumin also suppressed the induction of COX-2 mRNA by CD and PMA. ${ }^{[50]}$ To investigate the effect of curcumin on COX-2 expression, HT-29 human colon cancer cells were treated with various concentrations of curcumin. Curcumin inhibited the cell growth of HT-29 cells in a concentration and time-dependent manner. There was a marked inhibition of mRNA and protein expression of COX-2, but not COX-1. ${ }^{[51]}$

Kim et al demonstrated that the inhibitory action of curcumin on Janus kinase (JAK)-STAT signalling could contribute to its antiinflammatory activity in the brain. ${ }^{[52]}$ In both rat primary microglia and murine BV2 microglial cells, curcumin effectively suppressed the ganglioside, Lipopolysaccharide (LPS) or interferon (IFN- $\gamma$ )-stimulated induction of COX-2 and inducible NO synthase, important enzymes that mediate inflammatory processes. Curcumin markedly inhibited the phosphorylation of STAT1 and 3 as well as JAK1 and 2 in microglia activated with gangliosides, LPS, or IFN-gamma thus attenuating inflammatory response of brain microglial cells. ${ }^{[52]}$

\section{Inhibition of prostaglandin synthesis}

Effect of some biochemical changes produced during subacute inflammation in rats has been studied and compared with ibuprofen. ${ }^{53]}$ Curcumin in the doses of 100 and $200 \mathrm{mg} /$ $\mathrm{kg}$ inhibited the granuloma formation by 21.7 and $30.8 \%$, respectively, while ibuprofen in 15 and $20 \mathrm{mg} / \mathrm{kg}$ doses inhibited by 26.6 and $32.2 \%$, respectively. Thus, ibuprofen was found to be 10 times more potent than curcumin on weight basis. In an in vitro study, curcumin $(20 \mu \mathrm{g} / \mathrm{ml})$ as well as ibuprofen $(2 \mu \mathrm{g} /$ $\mathrm{ml}$ ) caused complete inhibition of the spontaneous contraction of the isolated pregnant rat uterus.

In an in vivo study, $\mathrm{PGE}_{2}$ content in the inflammatory exudates of control rats with inflammation was $7.29 \mu \mathrm{g} / \mathrm{ml}$. Treatment of the animals with curcumin $(200 \mathrm{mg} / \mathrm{kg})$ and ibuprofen $\left(20 \mathrm{mg} / \mathrm{kg}\right.$ ) for 4 days reduced the $\mathrm{PGE}_{2}$ content of the exudates by $45 \%$ and $61 \%$, respectively. Thus, curcumin was found to be less effective than ibuprofen in inhibiting PG synthesis in inflammatory exudates as well as in the in vitro system. In vitro studies revealed that curcumin decreased phorbol ester-induced $\mathrm{PGE}_{2}$ production down to almost preinduction level. ${ }^{54]}$ Tetrahydrocurcumin, hexahydrocurcumin and curcumin sulfate reduced it by $31 \%, 37 \%$ and $22 \%$, respectively. Hexahydrocurcuminol was found to be devoid of inhibitory activities. In a confirmatory Western analysis using a COX-2 monoclonal antibody, curcumin was shown to reduce phorbol ester-induced COX-2 protein expression consistently by $60-70 \%$. In contrast, curcumin metabolites interfered with
COX-2 protein inhibition only weakly. ${ }^{[54]}$

\section{Inhibition of cytokines}

The pleiotropic cytokine-tumour necrosis factor-alpha (TNF) induced the production of interleukin-1 beta (IL-1), and together, they play significant roles in many acute and chronic inflammatory diseases. Gupta et al. demonstrated that curcumin inhibited TNF- $\alpha$ induced expression of adhesion molecules (ICAM-1, VCAM-1 and E-selectin) on human umbilical vein endothelial cells. ${ }^{[5]}$ As diferuloylmethane significantly blocks the cytokine-induced transcript levels for the leukocyte adhesion molecules, it may be interfering at an early stage of signalling event induced by TNF- $\alpha .{ }^{[55]}$ Curcumin produced significant inhibition of IL-1 $\beta$ and IL-8 but minimal inhibition of TNF- $\alpha$ expression by preterm lung inflammatory cells at $20 \mu \mathrm{M}$ concentrations. Adult PBMC expression of IL-8 was significantly inhibited by curcumin at $20 \mu \mathrm{M}$ concentrations. Therefore, curcumin inhibits pro-inflammatory cytokine production (TNF- $\alpha$, IL-1 $\beta$ and IL-8) by lung inflammatory cells and this is evidenced by a large number of experiments. ${ }^{[56]-[60]}$ It was also shown that curcumin inhibited experimental allergic encephalomyelitis by blocking IL-12 signalling through JAK-STAT pathway in T lymphocytes. ${ }^{[61]}$

\section{$N F-\kappa B$ inhibition}

Binding of plasma factor VII (a) to tissue factor (TF) initiates the coagulation cascade. In normal condition, TF is not expressed in endothelial cells. However, endothelial cells express TF in response to LPS, TNF and other biological stimuli. Pendurthi et al studied the inhibition of TF gene activation in cultured endothelial cells by curcumin. ${ }^{[62]}$ They demonstrated that curcumin inhibited PMA, LPS, TNF- $\alpha$ and thrombininduced TF activity and TF gene transcription in human endothelial cells by impairing the proteolytic degradation inhibitor protein $\mathrm{I} \kappa \mathrm{B} \alpha$. Thus antiinflammatory and anticarcinogenic activity of curcumin may be related to its ability to inhibit cellular gene expression regulated by transcription factors NF- $\kappa$ B, AP-1 and Egr-1. ${ }^{[54]}$ Bierhaus demonstrated that curcumin inhibited TNF $\alpha$-induced Iк $\mathrm{B} \alpha$ degradation and the nuclear import of NF- $\alpha \mathrm{B}$. In contrast, inhibition of AP-1 was due to a direct interaction of curcumin with AP-1-binding to its DNA binding motif. Thus, curcumin inhibits NF- $\kappa \mathrm{B}$ and AP-1 by two different mechanisms and reduces expression of endothelial genes controlled by both transcription factors in vitro. ${ }^{[55]}$ Curcumin also blocks cytokinemediated NF- $\kappa$ B activation and pro-inflammatory gene expression by inhibiting inhibitory factor I- $\kappa \mathrm{B}$ kinase activity and it has been confirmed by a large number of experiments. ${ }^{[60-}$ ${ }^{[70]}$ The COX-2 inducible and nitric oxide synthase (iNOS) are important enzymes that mediate inflammatory responses. Improper up-regulation of COX-2 and iNOS has been associated with pathophysiology of certain types of human cancers as well as inflammatory disorders.

Recent studies have demonstrated that eukaryotic transcription factor nuclear factor $\kappa \mathrm{B}(\mathrm{NF}-\kappa \mathrm{B})$ was involved in regulation of COX-2 and iNOS expression. Surh studied the molecular mechanism underlying antiinflammatory activity of curcumin. ${ }^{\text {[11] }}$ They suggested the down-regulation of COX-2 and iNOS through suppression of NF- $\kappa$ B. Repression of degradation of the inhibitory unit I- $\kappa \mathrm{B} \alpha$, which hampers subsequent nuclear translocation of the functionally active subunit of $N F-\kappa B$, 
may be responsible for inhibition of NF- $\kappa$ B by curcumin. ${ }^{171}$ Pan et al comparatively studied suppression of nitric oxide synthase by curcumin and its hydrogenated metabolites through down-regulation of $\mathrm{I}-\kappa \mathrm{B}$ kinase and NF- $\mathrm{KB}$ activation in macrophages. ${ }^{[72]}$

Han et al demonstrated that curcumin inhibited the 12-Otetradecanoylphorbol-13-acetate (TPA)-induced NF- $\mathrm{B}$ activation by preventing the degradation of the inhibitory protein I- $\mathrm{KB} \alpha$ and the subsequent translocation of the p65 subunit in cultured human promyelocytic leukemia (HL-60) cells. ${ }^{[3]}$ Alternatively, curcumin repressed the TPA-induced activation of NF- $\kappa \mathrm{B}$ through direct interruption of the binding of NF- $\kappa \mathrm{B}$ to its consensus DNA sequences. ${ }^{[73]}$

Chun et al demonstrated the effect of curcumin on TPAinduced expression of COX-2) in female mouse. ${ }^{[66]}$ Immuno histochemical analysis of TPA-treated mouse skin revealed enhanced expression of COX-2 localized primarily in epidermal layer, which was markedly suppressed by curcumin pretreatment. Curcumin treatment attenuated TPA-stimulated $\mathrm{NF}-\kappa \mathrm{B}$ activation in mouse skin, which was associated with its blockade of degradation of the inhibitory protein $\mathrm{I}-\mathrm{\kappa B} \alpha$ and of subsequent translocation of the p65 subunit to nucleus. ${ }^{174]}$

Inhibition of platelet aggregation

Shah et al studied the mechanism of platelet aggregation by curcumin. ${ }^{[40]}$ They showed that curcumin-inhibited platelet aggregation mediated by the platelet agonists epinephrine (200 $\mu \mathrm{M})$, ADP $(4 \mu \mathrm{M})$, platelet activating factor (PAF, $800 \mathrm{nM}$ ), collagen $(20 \mu \mathrm{g} / \mathrm{ml})$ and AA $(0.75 \mathrm{mM})$. Curcumin preferentially inhibited PAF and AA-induced aggregation (IC-50; 20-25 $\mu \mathrm{M}$ ) whereas much higher concentration of curcumin is required to inhibit aggregation induced by other platelet agonists. Pretreatment of platelets with curcumin resulted in inhibition of platelet aggregation induced by calcium ionophore A-23187 $\left(\mathrm{IC}_{50}: 100 \mu \mathrm{M}\right)$, but curcumin up to $250 \mu \mathrm{M}$ had no inhibitory effect on aggregation induced by the proteinkinase $C$ (PKC) activator phorbol myrisitate acetate $(1 \mu \mathrm{M})$. Curcumin $(100$ $\mu \mathrm{M})$ inhibited the A-23187-induced mobilization of intracellular $\mathrm{Ca}^{2+}$ as determined by using fura- 2 acetoxymethyl ester. Curcumin also inhibited the formation of thromboxane $\mathrm{A}_{2}$ (TX $\mathrm{A}_{2}$ ) by platelets $\left(\mathrm{IC}_{50}: 70 \mu \mathrm{M}\right)$. These results suggest that the curcumin-mediated preferential inhibition of PAF and AAinduced platelet aggregation which involved inhibitory effects on $\mathrm{TXA}_{2}$ synthesis and $\mathrm{Ca}^{2+}$ signalling but without the involvement of PKC.

\section{Stabilization of lysosomal enzymes}

A number of NSAIDs like ketoprofen, suprofen have been reported to inhibit the release of lysosomal enzymes from the neutrophils. ${ }^{\mid 75]}$ The role of lysosomal enzymes, i.e. acid phosphatase and cathepsin D as mediator of inflammation is well documented. ${ }^{[76],[77]}$ Stabilization of lysosomal enzymes by curcumin and ibuprofen was compared. Serum phosphatase activity increased from 7.26 to 15.4 units $(+112 \%)$ due to inflammation. Curcumin $(200 \mathrm{mg} / \mathrm{kg})$ prevented the increase by $50 \%$ while ibuprofen $(20 \mathrm{mg} / \mathrm{kg}$ ) prevented it by $61 \%$. In an in vitro study, curcumin was found to have greater lysosomal membrane stabilization effect than ibuprofen. ${ }^{[53]}$ Joe et al demonstrated that curcumin and capsaicin lower the release of lysosomal enzymes and eicosanoids in rat peritoneal macrophages. ${ }^{[29]}$

\section{Release of hormones}

The release of endogenous corticosteroids by curcumin may also help indirectly in stabilizing lysosomal membrane, because glucocorticoids are known to have stabilizing effect on the lysosomal enzymes as evidenced by several experiments. ${ }^{\text {[78, }[79]}$ Inflammation caused a significant increase in adrenal ascorbic acid and cholesterol level. A dose of $200 \mathrm{mg} / \mathrm{kg}$ of curcumin significantly decreased the adrenal ascorbic acid without affecting the cholesterol level. ${ }^{[53]}$ Lower dose of curcumin (100 $\mathrm{mg} / \mathrm{kg}$ ) as well as ibuprofen had no effect. ${ }^{[53]}$

\section{Antioxidative effect}

Curcumin was found to be a very potent antioxidant. ${ }^{[80]-[83]}$ Curcumin was found to generate hydroxyl radicals through the Fenton reaction by reducing $\mathrm{Fe}^{3+}$ to $\mathrm{Fe}^{2+}{ }^{\text {.84] }}$ Effect of curcumin as superoxide scavenger was studied and curcumin was found to be a potent scavenger of superoxide. ${ }^{[85]}$ They also reported a better correlation between antiinflammatory activity and superoxide scavenging property.

Balasubramanyam et al demonstrated that curcumin abolished both PMA and thapsigargin-induced ROS generation in cells from control and diabetic subjects. The pattern of these ROS inhibitory effects as a function of dose-dependency suggest that curcumin mechanistically interferes with PKC and calcium regulation. ${ }^{86]}$

Priyadarsini et al tested the antioxidant activity of curcumin and dimethoxy curcumin by radiation-induced lipid peroxidation in rat liver microsomes. ${ }^{[87]}$ They found that at equal concentration, the efficiency to inhibit lipid peroxidation is changed from $82 \%$ with curcumin to $24 \%$ with dimethoxy curcumin. These results suggested that, although the energetics to remove hydrogen from both phenolic $\mathrm{OH}$ and the $\mathrm{CH}(2)$ group of the beta-diketo structure were very close, the phenolic $\mathrm{OH}$ was essential for both antioxidant activity and free radical kinetics. This was further confirmed by density functional theory (DFT) calculations where it was shown that the $-\mathrm{OH}$ hydrogen was more labile for abstraction compared to the CH (2) hydrogen in curcumin suggesting that phenolic $\mathrm{OH}$ plays a major role in the activity of curcumin.

\section{Inhibition of monocyte chemoattractant protein-1 (mcp-1)} by curcumin

Nakayama et al described a novel effect of proteosome inhibitors on the expression of the monocyte chemoattractant protein 1 (MCP-1) in mesangial cells. They found that proteosome inhibitors MG 132 dose-dependently induced the expression of MCP-1 at the transcriptional level. The 5'-flanking region of the MCP-1 gene contains multiple AP-1 sites. A reporter assay showed that AP-1 activity was up-regulated after treatment with MG 132 and kinase assay revealed that c-jun-N-terminal kinase (JNK) was rapidly activated by MG132. Curcumin, a pharmacological inhibitor of the JNK-AP-1 pathway, abrogated the induction of MCP-1 by MG132. These data revealed that proteosome inhibition triggered the expression of MCP-1 and other genes via the multistep induction of the JNK-c-Jun/AP-1 pathway. ${ }^{[88]}$ 
Inhibition of acidic glycoprotein (gp a 72) by curcumin

Joe $e t$ al. observed an increased level of acidic glycoprotein Gp A 72 in the sera of arthritic rats. ${ }^{[89]}$ The appearance of Gp A 72 in the serum preceded the onset of the paw inflammation in the arthritic rats and persisted in the chronic phase. They found that oral administration of antiinflammatory spices like capsaicin and curcumin lowered the levels of Gp A72 by $88 \%$ and $73 \%$, respectively, with concomitant lowering of paw volume in the arthritic rats.

Zsila et al demonstrated binding of curcumin molecule to human alpha1-acid glycoprotein (AGP), an acute phase protein in blood. ${ }^{[90]}$ Oppositely signed induced circular dichroism (CD) bands measured in the visible spectral region in $\mathrm{pH} 7.4$ phosphate buffer indicated that the protein bounded curcumin molecule in a left-handed chiral conformation. Curcumininduced changes in the tertiary structure of AGP, which lead to the decreased binding affinity.

\section{Conclusion}

A large number of studies have revealed that curcumin has wide therapeutic actions such as antiinflammatory, antispasmodic, antimicrobial, anticancer, hepatoprotection and neuroprotection etc. Its antiinflammatory activity is mainly due to inhibition of AA metabolism, COX, LOX, cytokines (ILs and TNF) and NF-кB. Curcumin is reported to stabilize lysosomal membrane and causes uncoupling of oxidative phosphorylation besides having strong oxygen radical scavenging activity. The most interesting feature of curcumin is lack of gastrointestinal side effects despite being an antiinflammatory agent. Thus curcumin may prove as a useful drug for treatment of diseases such as arthritis, cancer, HIV etc. More research work is needed in order to explore its new areas of therapeutic applications.

\section{References}

1. Nadkarni AK. Indian Materia Medica. Bombay: Popular Prakashan PVP; 1954.

2. Leung A. Encyclopedia of common natural ingredients used in food, drugs \& cosmetics. John Weily 198;31: 314.

3. Chandra D, Gupta S. Anti-inflammatory and anti-arthritic activity of volatile oil of Curcuma longa (Haldi). Indian J Med Res 1972;60:138-42.

4. Cooper TH, Clark G, Guzinski J. In: Chi-Tang Ho, editor. Am Chem Soc Washington, DC, 1994; 23: 231-6.

5. Arora R, Basu N, Kapoor V. Anti-inflammatory studies on Curcuma longa (turmeric). Indian J Med Res 1971;59:1289-95.

6. Negi PS, Jayaprakasha GK, Jagan Mohan Rao L, Sakariah KK. Antibacterial activity of turmeric oil: a byproduct from curcumin manufacture. J Agric Food Chem 1999;47:4297-300.

7. Bourne KZ, Bourne N, Reising SF, Stanberry LR. Plant products as topical microbicide candidates: assessment of in vitro and in vivo activity against herpes simplex virus type 2. Antiviral Res 1999;42:219-26.

8. Apisariyakul A, Vanittanakom N, Buddhasukh D. Antifungal activity of turmeric oil extracted from Curcuma longa (Zingiberaceae). J Ethnopharmacol 1995;49:163-9.

9. Kawamori T, Lubet R, Steele VE. Chemopreventative effect of curcumin, a naturally occurring anti-inflammatory agent, during the promotion/progression stages of colon cancer. Cancer Res 1999;59:597-601.

10. Itthipanichpong C, Ruangrungsi N, Kemsri W, Sawasdipanich A. Antispasmodic effects of curcuminoids on isolated guinea-pig ileum and rat uterus. $J$ Med Assoc Thai 2003;86:299-309.

11. Park $\mathrm{E} J$, Jeon $\mathrm{CH}, \mathrm{Ko}$ G. Protective effect of curcumin in rat liver injury induced by carbon tetrachloride. J Pharm Pharmacol 2000;52:437-40.

12. Mazumder A, Wang S, Neamati N, Nicklaus M, Sunder S, Chen J, et al. Antiretroviral agents as inhibitors of both human immunodeficiency virus type 1integrase and protease. J Med Chem 1996:39:2472-81.

13. Sui Z, Salto R, Li J, Craik C, Ortiz de Montellano PR. Inhibition of the HIV-1 and HIV-2 proteases by curcumin and curcumin boron complexes. Bioorg Med Chem 1993;1:415-22.

14. James JS. AIDS Treatment News; 1993;176:1-3.

15. Srimal RC, Khanna NM, Dhawan BN. A preliminary report on anti inflammatory activity of curcumin. Int J Pharm 1971;3:10.

16. Srimal RC, Dhawan BN. Pharamacology of diferuloyl methane, a non steroidal anti-inflammatory drug. J Pharm Pharmacol 1973;25:447.

17. Mukhopadhyay A, Basu N, Ghatak N. Anti-inflammatory and irritant activities of curcumin analogues in rats. Agents Actions 1982;12:508-15.

18. Srinivasan KR. A chromatographic study of the curcuminoids in curcuma longa Linn. J Pharm Pharmacol 1953;5:448-53.

19. Rao TS, Basu N, Siddiqui HH. Anti-inflammatory activity of curcumin analogues. Indian J Med Res 1982;75:574-8.

20. Ghatak N, Basu N. Sodium curcuminate as an effective anti-inflammatory agent. Indian J Exp Biol 1972;10:235-6.

21. Mukhopadhyay A, Basu N, Ghatak N, Gujral PK. Structure activity relationship with respect to anti-inflammatory activity in a series of curcumin analogues. Proc Int Union Physiol Sci 1974;10:241-5.

22. Deodhar SD, Sethi R, Srimal RC. Preliminary study on antirheumatic activity of curcumin (Diferuloyl methane). Indian J Med Res 1980;71:632-43.

23. Satoskar RR, Shah SJ, Shenoy SG. Evaluation of anti-inflammatory property of curcumin in patients with post operative inflammation. Int J Clin Pharmacol Ther Toxicol 1986;24:651-4.

24. Kuttan R, Sudheeran PC, Joseph CD. Turmeric and curcumin as topical agents in cancer therapy. Tumori 1987;73:29-31.

25. Lal B, Kapoor AK, Asthana OP, Agrawal PK, Prasad R, Kumar P, et al. Efficacy of curcumin in the management of chronic anterior uveitis. Phytother Res 1999;13:318-22

26. Lal B, Kapoor AK, Agrawal PK, Asthana OP, Srimal RC. Role of curcumin in idiopathic inflammatory orbital pseudotumours. Phytother Res 2000;14:443-7.

27. Srivastava KC, Bordia A, Verma SK. Curcumin, a major component of food spice turmeric (Curcuma longa) inhibits aggregation and alters eicosanoid metabolism in human blood platelets. Prostaglandins Leukot Essent Fatty Acids 1995;52:223-7.

28. Conney AH, Lysz T, Ferraro T, Abidi TF, Manchand PS, Laskin JD, Huang MT. Inhibitory effect of curcumin and some related dietary compounds on tumor promotion and arachidonic acid metabolism in mouse skin. Adv Enzyme Regul 1991;31:385-96.

29. Joe B, Lokesh BR. Effect of curcumin and capsaicin on arachidonic acid metabolism and lysosomal enzyme secretion by rat peritoneal macrophages. Lipids 1997;32:1173-80.

30. Ammon HP, Safayhi H, Mack T, Sabieraj J. Mechanism of anti-inflammatory actions of curcumin and bowsellic acids. J Ethnopharmacol 1993;38:113-9.

31. Srivastava R. Inhibition of neutrophil response by curcumin. Agents Actions 1989;28:298-303.

32. Ramsewak RS, DeWitt DL, Nair MG. Cytotoxicity, antioxidant and antiinflammatory activities of curcumins I-III from Curcuma longa. Phytomedicine 2000;7:303-8

33. Skrzypczak-Jankun E, McCabe NP, Selman SH, Jankun J. Curcumin inhibits lipoxygenase by binding to its central cavity: theoretical and X-ray evidence. Int J Mol Med 2000;6:521-6.

34. Wallace JM. Nutritional and botanical modulation of the inflammatory cascade-eicosanoids, cyclooxygenases and lipoxygenases-as an adjunct in cancer therapy. Integr Cancer Ther 2002;1:7-37.

35. Huang MT, Lysz T, Ferraro T, Abidi TF, Laskin JD, Conney AH. Inhibitory effects of curcumin on in vitro lipoxygenase and cyclooxygenase activities in mouse epidermis. Cancer Res 1991;51:813-9.

36. Flynn DL, Rafferty MF, Boctor AM. Inhibition of 5-hydroxy-eicosatetraenoic acid (5-HETE) formation in intact human neutrophils by naturally-occurring diarylheptanoids: Inhibitory activities of curcuminoids and yakuchinones. Prostaglandins Leukot Med 1986;22:357-60.

37. Lukita-Atmadja W, Ito Y, Baker GL, McCuskey RS. Effect of curcuminoids as anti-inflammatory agents on the hepatic microvascular response to endotoxin. Shock 2002;17:399-403.

38. Gukovsky I, Reyes CN, Vaquero EC, Gukovskaya AS, Pandol SJ. Curcumin ameliorates ethanol and nonethanol experimental pancreatitis. Am J Physiol Gastrointest Liver Physiol 2003;284:85-95.

39. Ukil A, Maity S, Karmakar S, Datta N, Vedasiromoni JR, Das PK. Curcumin, 
the major component of food flavour turmeric, reduces mucosal injury in trinitrobenzene sulphonic acid-induced colitis. Br J Pharmacol 2003;139:20918.

40. Shah BH, Nawaz Z, Pertani SA, Roomi A, Mahmood H, Saeed SA, et al. Inhibitory effect of curcumin, a food spice from turmeric, on platelet-activating factor- and arachidonic acid-mediated platelet aggregation through inhibition of thromboxane formation and $\mathrm{Ca}^{2+}$ signaling. Biochem Pharmacol 1999:58:1167-72.

41. Srivastava KC, Bordia A, Verma SK. Curcumin, a major component of food spice turmeric (Curcuma longa) inhibits aggregation and alters eicosanoid metabolism in human blood platelets. Prostaglandins Leukot Essent Fatty Acids 1995:52:223-7.

42. Chan MM. Inhibition of tumor necrosis factor by curcumin, a phytochemical. Biochem Pharmacol 1995;49:1551-6.

43. Kobayashi T, Hashimoto S, Horie T. Curcumin inhibition of Dermatophagoides farinea-induced interleukin-5 (IL-5) and granulocyte macrophage-colony stimulating factor (GM-CSF) production by lymphocytes from bronchial asthmatics. Biochem Pharmacol 1997;54:819-24.

44. Abe $\mathrm{Y}$, Hashimoto S, Horie T. Curcumin inhibition of inflammatory cytokine production by human peripheral blood monocytes and alveolar macrophages. Pharmacol Res 1999;39:411-7.

45. Kang BY, Chung SW. Inhibition of interleukin-12 production in lipopolysaccharide-activated macrophages by curcumin. Eur J Pharmacol 1999;384:191-5.

46. Kondo A, Koshihara Y, Togari A. Signal transduction system for interleukin-6 synthesis stimulated by lipopolysaccharide in human osteoblasts. J Interferon Cytokine Res 2001;21:943-50.

47. Ruby AJ, Kuttan G. Anti-tumour and antioxidant activity of natural curcuminoids. Cancer Lett 1995;94:79-83.

48. Selvam R, Subramanian L. The anti-oxidant activity of turmeric (Curcuma longa). J Ethnopharmacol 1995;47:59-67.

49. Kunchandy E, Rao MNA. Oxygen radical scavenging activity of curcumin. Int J Pharm 1990;58:237-40.

50. Zhang F, Altorki NK, Mestre JR, Subbaramaiah K, Dannenberg AJ. Inhibition of cyclo-oxygenase 2 expression in colon cells by the chemopreventive agent curcumin involves inhibition of NF-kappaB activation via the NIK/IKK signaling complex. Carcinogenesis 1999;20:445-51.

51. Goel A, Boland CR, Chauhan DP. Specific inhibition of cyclooxygenase-2 (COX2) expression by dietary curcumin in HT-29 human colon cancer cells. Cancer Lett 2001;172:111-8.

52. Kim HY, Park EJ, Joe EH, Jou I. Curcumin suppresses Janus kinase-STAT inflammatory signaling through activation of Src homology 2 domain-containing tyrosine phosphatase 2 in brain microglia. J Immuno 2003;171:6072-9.

53. Srivastava R, Srimal RC. Modification of certain inflammation-induced biochemical changes by curcumin. Indian J Med Res 1985;81:215-23.

54. Ireson C, Orr S, Jones DJ, Verschoyle R, Lim CK, Luo JL, et al.Characterization of metabolites of the chemopreventive agent curcumin in human and rat hepatocytes and in the rat in vivo, and evaluation of their ability to inhibit phorbol ester-induced prostaglandin E2 production. Cancer Res 2001;61:1058-64.

55. Gupta B, Ghosh B. Curcuma longa inhibits TNF-alpha induced expression of adhesion molecules on human umbilical vein endothelial cells. Int $\mathrm{J}$ Immunopharmacol 1999;21:745-57.

56. Literat A, Su F, Norwicki M, Durand M, Ramanathan R, Jones CA, et al. Regulation of pro-inflammatory cytokine expression by curcumin in hyaline membrane disease (HMD). Life Sci 2001;70:253-67.

57. Banerjee M, Tripathi LM, Srivastava VM, Puri A, Shukla R. Modulation of inflammatory mediators by ibuprofen and curcumin treatment during chronic inflammation in rat. Immunopharmacol Immunotoxicol 2003;25:213-24.

58. Gaddipati JP, Sundar SV, Calemine J, Seth P, Sidhu GS, Maheshwari RK. Differential regulation of cytokines and transcription factors in liver by curcumin following hemorrhage/resuscitation. Shock 2003;19:150-6.

59. Huang CD, Tliba O, Panettieri RA Jr, Amrani Y. Bradykinin induces interleukin6 production in human airway smooth muscle cells: Modulation by Th2 cytokines and dexamethasone. Am J Respir Cell Mol Biol 2003:28:330-8.

60. Xu YX, Pindolia KR, Janakiraman N, Chapman RA, Gautam SC. Curcumin inhibits IL1 alpha and TNF-alpha induction of AP-1 and NF-KB DNA-binding activity in bone marrow stromal cells. Hematopathol Mol Hematol 1997-98;11: 49-62.

61. Natarajan C, Bright JJ. Curcumin inhibits experimental allergic encephalomyelitis by blocking IL-12 signaling through Janus kinase-STAT pathway in T lymphocytes. J Immunol 2002;168:6506-13.
62. Pendurthi UR, Williums JT, Rao LV. Inhibition of tissue factor gene activation in cultured endothelial cells by curcumin. Suppression of activation of transcription factors Egr-1, AP-1 and NF Kappa B. Arterioscler Thromb Vase Bio 1997;17:3406-13.

63. Bierhaus A, Zhang Y, Quehenberger P, Luther T, Haase M, Muller M, et al. The dietary pigment curcumin reduces endothelial tissue factor gene expression by inhibiting binding of AP-1 to the DNA and activation of NF-kappa B. Thromb Haemost 1997;77:772-82.

64. Singh S, Aggarwal BB. Activation of transcription factor NF-kappa B is suppressed by curcumin (diferuloylmethane). J Biol Chem 1995;270:249955000 .

65. Brennan $\mathrm{P}, \mathrm{O}^{\prime}$ Neill LA. Inhibition of nuclear factor kappa B by direct modification in whole cells--mechanism of action of nordihydroguaiaritic acid, curcumin and thiol modifiers. Biochem Pharmacol 1998:55:965-73.

66. Jobin C, Bradham CA, Russo MP, Juma B, Narula AS, Brenner DA, Sartor RB. Curcumin blocks cytokine-mediated NF-kappa B activation and proinflammatory gene expression by inhibiting inhibitory factor I-kappa B kinase activity. J Immunol 1999;163:3474-83.

67. Bremner $P$, Heinrich $M$. Natural products as targeted modulators of the nuclear factor-kappa B pathway. J Pharm Pharmacol 2002;54:453-72.

68. Sugimoto K, Hanai H, Tozawa K, Aoshi T, Uchijima M, Nagata T, et al. Curcumin prevents and ameliorates trinitrobenzene sulfonic acid-induced colitis in mice. Gastroenterology 2002;123:1912-22.

69. Bharti AC, Donato N, Singh S, Aggarwal BB. Curcumin (diferuloylmethane) down-regulates the constitutive activation of nuclear factor-kappa $B$ and IkappaBalpha kinase in human multiple myeloma cells, leading to suppression of proliferation and induction of apoptosis. Blood 2003;10:1053-62.

70. Nanji AA, Jokelainen K, Tipoe GL, Rahemtulla A, Thomas P, Dannenberg AJ. Curcumin prevents alcohol-induced liver disease in rats by inhibiting the expression of NF-kappa B-dependent genes. Am J Physiol Gastrointest Liver Physiol 2003;284:321-7.

71. Surh YJ, Chun KS, Cha HH, Han SS, Keum YS, Park KK, et al. Molecular mechanism underlying chemopreventive activities of anti-inflammatory phytochemicals: down regulation of COX-2 and iNOS through suppression of NF-kappa B activation. Mutation Res 2001;480:243-68.

72. Pan MH, Lin-Shiau SY, Lin JK. Comparative studies on the suppression of nitric oxide synthase by curcumin and its hydrogenated metabolites through down-regulation of Ikappa B kinase and NF kappa B activation in macrophages. Biochem Pharmacol 2000;60:1665-76.

73. Han SS, Keum YS, Seo HJ, Surh YJ. Curcumin suppresses activation of NFkappaB and AP-1 induced by phorbol ester in cultured human promyelocytic leukemia cells. J Biochem Mol Biol 2002;35:337-42.

74. Chun KS, Keum YS, Han SS, Song YS, Kim SH, Surh YJ. Curcumin inhibits phorbol ester-induced expression of cyclooxygenase-2 in mouse skin through suppression of extracellular signal-regulated kinase activity and NF-kappaB activation. Carcinogenesis 2003;24:1515-24.

75. Smith RJ. Nonsteroidal anti-inflammatory agents: Regulators of the phagocytic secretion of lysosomal enzymes from guinea pig neutrophils. J Pharmacol Exp Ther 1978;207:618.

76. Weismann $\mathrm{G}$. The role of lysozymes in inflammation and disease. Annu Rev Med 1967;18:97.

77. Becker EL, Henson PM. In vitro studies of immunologically induced secretion of mediators from cell and related phenomena. Adv Immunol 1973;17:93.

78. Ignaro LJ. Lysosome membrane stabilization in vivo: Effects of steroidal and non-steroidal anti-inflammatory drugs on the integrity of rat liver lysosomes. J Pharmacol Exp Ther 1972;182:179.

79. Winter CA. Non-steroidal anti-inflammatory agents. Annu Rev Pharmacol 1966;6:157.

80. Sharma OP. Antioxidant activity of curcumin and related compounds. Biochem Pharmacol 1976;25:1811-5.

81. Unnikrishnan MK, Rao MN. Inhibition of nitrite induced oxidation of hemoglobin by curcuminoids. Pharmazie 1995;50:490-2.

82. Osawa T, Sugiyama Y, Inayoshi M, Kawakishi S. Antioxidative activity of tetrahydrocurcuminoids. Biosci Biotechnol Biochem 1995;59:1609-12.

83. Iqbal M, Sharma SD, Okazaki Y, Fujisawa M, Okada S. Dietary supplementation of curcumin enhances antioxidant and phase II metabolizing enzymes in ddY male mice: Possible role in protection against chemical carcinogenesis and toxicity. Pharmacol Toxicol 2003:92:33-8.

84. Elizabeth K, Rao MNA. Effect of curcumin on hydroxyl radical generation through Fenton reaction. Int J Pharm 1989;57:173-6. 
85. Elizabeth $\mathrm{K}$, Rao MNA. Oxygen radical scavenging activity of curcumin. Int $\mathrm{J}$ Pharm 1990;58:237-40.

86. Balasubramanyam M, Koteswari AA, Kumar RS, Monickaraj SF, Maheswari JU, Mohan V. Curcumin-induced inhibition of cellular reactive oxygen species generation: Novel therapeutic implications. J Biosc 2003;28:715-21.

87. Priyadarsini KI, Maity DK, Naik GH, Kumar MS, Unnikrishnan MK, Satav JG, et al. Role of phenolic $\mathrm{O}-\mathrm{H}$ and methylene hydrogen on the free radical reactions and antioxidant activity of curcumin. Free Radic Biol Med 2003;35:475-84.

88. Nakayama K, Furusu A, Xu Q, Konta T, Kitamura M. Unexpected transcrip- tional induction of monocyte chemoattractant protein 1 by proteasome inhibition: involvement of the c-Jun $\mathrm{N}$-terminal kinase-activator protein 1 pathway. J Immunol 2001:167:1145-50.

89. Joe B, Rao UJ, Lokesh BR. Presence of an acidic glycoprotein in the serum of arthritic rats: modulation by capsaicin and curcumin. Mol Cell Biochem 1997;169:125-34.

90. Zsila F, Bikadi Z, Simonyi M. Induced circular dichroism spectra reveal binding of the anti-inflammatory curcumin to human alpha1-acid glycoprotein. Bioorg Med Chem 2004;12:3239-4.

\title{
$38^{\text {th }}$ ANNUAL CONFERENCE INDIAN PHARMACOLOGICAL SOCIETY
}

Theme : Changing role of Pharmacologists in Modern Medicine Dec. $28^{\text {th }}-30^{\text {th }} 2005$

Preconference Workshop on Clinical Pharmacology 27 ${ }^{\text {th }}$ Dec. 2005

Venue : Madras Medical College - Chennai

\author{
Dr. C.B.Tharani \\ Organising Secretary
}

All correspondence to be mailed by registered post or courier to Marundeshwara Enterprises:

A2, Shanthi Apartments,

21, TTK 1st Cross Street,

Alwarpet, Chennai - 600018.
Ph:044-2435 7194,24353 079

Fax:044-24320605.

Email: marundeshwara_tours@vsnl.com.

\section{Registration Fees}

Category

IPS Member

Non-IPS Member

Student Delegate

Associate Delegate

Children (below-12 yrs)

Foreign Delegates

Pre Conference Workshop

Before

31.8.05

Rs. 1800
Rs. 2000
Rs. 1000
Rs. 1300
Rs. 700
US \$ 250

Category

IPS Member

Non-IPS Member

Foreign Delegates
Before

31.10.05

Rs. 2000

Rs. 2200

Rs. 1200

Rs. 1500

Rs.700

US \$ 300
On the Spot

Rs. 2500

Rs. 2700

Rs. 1500

Rs. 2000

Rs. 700

US \$ 400

\section{Workshop is limited to 50 participants only}

Fees

Rs. 500

Rs. 600

US $\$ 50$

*For outstation cheques please add Rs. 100 towards bank service charges.

**Spot Registration will be entertained only on cash payment. 